ROCZNIKI HUMANISTYCZNE

Tom LXIX, zeszyt $12-2021$

DOI: https://doi.org/10.18290/rh216912-9

ANDRZEJ PRASAŁ

\title{
IKONA NIEMIECKIEGO ORGELBEWEGUNG - ORGANY OŚRODKA JUGENDHOF HASSITZ W KŁODZKU-JURANDOWIE (GOSZYCACH)
}

Rosnące na początku XX wieku zainteresowanie muzyką organową czasów przeszłych doprowadziło do powstania w Niemczech Orgelbewegung, czyli ruchu dążącego do odnowy budownictwa organowego według wzorców barokowych (Busch). U podstaw reformy stały formułowane od końca XIX stulecia przez Émile'a Ruppa, a następnie przez Alberta Schweitzera idee powrotu do organów „bachowskich”. Za datę narodzin ruchu, zwanego przez jego założyciela Wilibalda Gurlitta „Ruchem Odnowy Organów”, uznać można kongres organowy, który odbył się we Freiburgu w 1926 r. Zgłoszone wówczas postulaty propagatorów ruchu (od ok. 1930 r. określanego w skróconej formie jako Orgelbewegung) zaowocowały zmianami w nastawieniu budowniczych organów. Niemiecki krąg organistów, organmistrzów i teoretyków zajmujących się problematyką budownictwa organowego i jego historią poddał krytyce jakiekolwiek wpływy romantyczne, zwracając się ku ideałom niemieckiego budownictwa XVII i XVIII wieku.

Do pierwszych instrumentów wybudowanych na Śląsku w duchu Orgelbewegung należały organy: Wyższej Szkoły Technicznej we Wrocławiu (1929 r.), Młodzieżowego Ośrodka Wypoczynkowo-Szkoleniowego w Kłodzku-Jurandowie (Jugendhof Hassitz, 1929 r.) oraz ewangelickiego kościoła św. Krzysztofa

Dr ANDRZej Prasat - Uniwersytet Opolski, Instytut Historii, Katedra Muzykologii; adres do korespondencji: ul. Strzelców Bytomskich 2, 45-084 Opole; e-mail: andrzej.prasal@uni.opole.pl; ORCID: https://orcid.org/00000-0002-2495-1543.

Dr AndRzej Prasal, University of Opole, Institute of History, Department of Musicology; address for correspondence: ul. Strzelców Bytomskich 2, 45-084 Opole, Poland; e-mail: andrzej.prasal@uni.opole.pl. ORCID: https://orcid.org/0000-0002-2495-1543. 
we Wrocławiu (1930 r.). Wszystkie wyznaczyły kierunki rozwoju niemieckiego, a ściślej śląskiego, organmistrzostwa (Walter, Orgelbau 103-5).

Jurandów (Hassitz) to część Kłodzka położona na prawym brzegu Nysy Kłodzkiej, na południe od centrum miasta (Stownik 184-87). Teren Jurandowa pokryty jest w części luźną zabudową, w części użytkami rolniczymi. Z wyższych punktów roztaczają się ładne widoki na miasto i jego otoczenie. Jurandów jest dzielnicą o zróżnicowanym charakterze. Znajdują się tu m.in. rozległe tereny kolejowe z dworcem oraz duży zespół szpitalny. Początkowo po II wojnie światowej Jurandów nazywano również Goszycami. Nazwa ta funkcjonuje do dziś.

Osadnictwo na terenie Jurandowa pojawiło się bardzo dawno, o czym świadczy odkrycie na terenie szpitala osady kultury łużyckiej. Jurandów, już jako wieś, powstał prawdopodobnie w I połowie XIII wieku. Z czasem miejscowość zmieniała się coraz bardziej w podmiejską osadę. W XV wieku zaczęły powstawać tu folwarki i dworki bogatych mieszczan kłodzkich, przy których osiedlano chłopów. Największe zmiany zaszły w Jurandowie w XVIII stuleciu, gdy powstała tu duża posiadłość barona Pillatiego, który wzniósł w dolnej części wsi okazały pałac (rozebrano go w latach pięćdziesiątych XX wieku). W II połowie XIX wieku Jurandów coraz bardziej łączył się z miastem, zwłaszcza po wzniesieniu na jego terenie dworca kolejowego. Dlatego już w $1890 \mathrm{r}$. wieś w całości włączono w obręb miasta i od tej pory rozwijała się już jako jego część. Na przełomie XIX i XX wieku na terenie Jurandowa wzniesiono duży kompleks szpitalny. W 1925 r. w najwyższym punkcie dzielnicy znalazł swoją siedzibę znany w całych Niemczech młodzieżowy ośrodek kultury.

Jugendhof Hasitz (dzisiaj Zespół Placówek Socjoterapeutycznych w Kłodzku-Jurandowie) powstał dzięki inicjatywie i zaangażowaniu jednego z głównych działaczy odnowy ruchu śpiewaczego w Niemczech (Finkensteiner Bund Singbewegung) - radcy szkolnego Richarda Poppego (1884-1960) (Menzel). Ośrodek otwarto 5 września 1925 r. i mieścił się w przebudowanym dawnym zajeździe (Preis 1: 46-47; Preis 2: 13-17). Szybko stał się centrum odnowy ruchu śpiewaczego dla Niemiec wschodnich (Kraus 197-99). Dysponował m.in. dużą świetlicą oraz 300 stałymi miejscami noclegowymi. Głównym punktem ośrodka była ukończona w 1928 r. i urządzona w stylu szwedzkim drewniana aula o dobrej akustyce. 


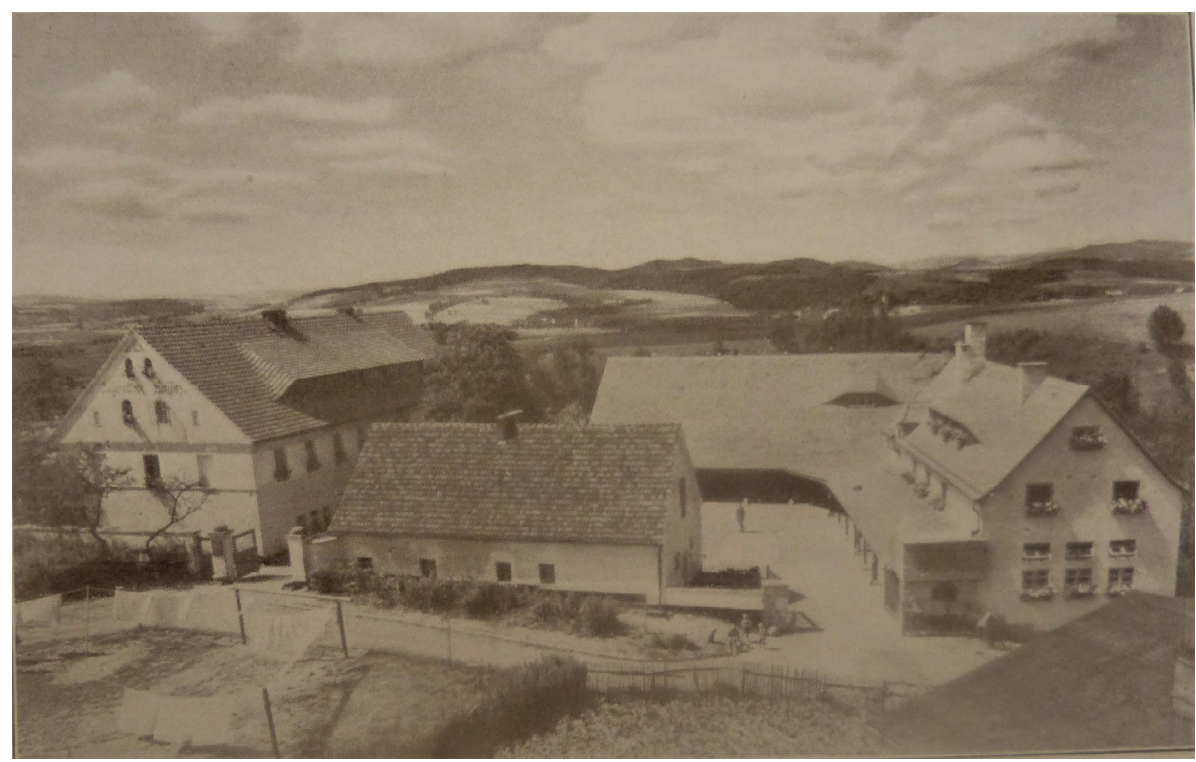

Fotografia 1. Jugendhof Hassitz (Musik und Kirche, z. 1, 1930)

Jugendhof Hassitz działał jako ośrodek odnowy ruchu śpiewaczego zaledwie siedem lat. W tym czasie przewinęło się przez niego kilkadziesiąt tysięcy osób. W 1930 r. liczba uczestników różnego rodzaju kursów wyniosła ponad 18 tysięcy, a w 1932 roku około 30 tysięcy. W 1933 roku ośrodek został przejęty przez organizację Hitlerjugend, która zmieniła profil jego działalności. W latach 1943-1945 mieściła się tu m.in. szkoła muzyczna (NS-Gebietsmusikschule).

Stworzona przez Poppego infrastruktura służyć miała wychowaniu patriotycznemu młodzieży, co miało się odbywać przede wszystkim poprzez rozbudzanie zamiłowania do szeroko pojętej niemieckiej kultury śpiewaczej, ze szczególnym naciskiem na pieśń masową, zarówno ludową, jak i religijną. W ośrodku urządzano m.in. kursy tańca ludowego, śpiewu oraz gry na dawnych instrumentach. $Z$ tego powodu zdecydowano o wyposażeniu ośrodka w organy (Ramin 34-37; Stępowski 144-46; Brylla 20-21). Inicjatorami tego przedsięwzięcia byli radca szkolny Poppe oraz kantor Max Reining.

Instrument nazwany Ver sacrum, czyli „Święta wiosna” miał upamiętniać i przypominać tych wszystkich, którzy poświęcili i oddali swoje życie za ojczyznę, zwłaszcza poległych w czasie I wojny światowej (Lönnecker 12-14). Nazwa nawiązywała do antycznego zwyczaju praktykowanego w chwilach zagrożenia lub niedostatku, polegającego na ślubowaniu ofiary ze wszystkich stworzeń narodzonych wiosną najbliższego roku (Członkowska-Naumiuk). 
Ponieważ jednak uważano za zbyt okrutne składanie w ofierze dzieci, zabijano tylko zwierzęta, a dzieci poświęcano bogu. Z chwilą osiągnięcia pełnoletności poświęceni musieli opuścić rodzinną ziemię i wyruszyć w poszukiwaniu nowego miejsca do życia.

Budowę organów powierzono znanej firmie organmistrzowskiej Sauer z Frankfurtu n. Odrą. Dyspozycję instrumentu opracował czołowy przedstawiciel Orgelbewegung dr Christhard Mahrenholz. Przedstawiała się ona następująco (Ramin 36-37; Zeitschrift; Burgemeister 268; Walter, Die Orgeln 273-74; Falkenberg 75-76) ${ }^{1}$ :

\begin{tabular}{|c|c|c|}
\hline $\begin{array}{l}\text { Hauptwerk } \\
\mathrm{C}-\mathrm{g}^{3}\end{array}$ & $\begin{array}{l}\text { Oberwerk } \\
\mathrm{C}-\mathrm{g}^{3} \\
\text { żaluzja }\end{array}$ & $\begin{array}{l}\text { Pedal } \\
\text { C-f }\end{array}$ \\
\hline Prinzipal 8' & Lieblich Gedackt 8' & Subbaß 16' \\
\hline Rohrflöte $8^{\prime}$ & Quintaden $8^{\prime}$ & Prinzipal $8^{\prime}$ (Tr.) \\
\hline Gemshorn 8' & Violflöte $8^{\prime}$ & Rohrflöte $8^{\prime}$ (Tr.) \\
\hline Oktave 4' & Prinzipal 4' & Oktave 4' (Tr.) \\
\hline Rauschpfeife 2 fach & Gedacktflöte 4' & Rauschpfeife 2 fach (Tr.) \\
\hline Cymbel 3 fach & Quinte $2^{2} / 3^{\prime}$ & Dulzian 16' (Tr.) \\
\hline Dulcian 16' & Oktave 2' & Singend Cornett 2 \\
\hline & Nachthorn 2' & \\
\hline & Terz $1^{3} / 5^{\prime}$ & \\
\hline & Blockflöte 1' & \\
\hline & Krummhorn 8' & \\
\hline
\end{tabular}

Połączenia: Oberwerk/Hauptwerk, Hauptwerk/Pedal, Oberwerk/Pedal

Kombinacje: Handregister, Freie Kombination, Tutti

Urządzenia dodatkowe: Walze mit Gruppenschaltung, Schwelltritt für Oberwerk

Organy umieszczono na balkonie auli. Stół gry wbudowany był centralnie w cokół szafy organowej. Cały mechanizm instrumentu skryty był za rzadko stosowaną formą prospektu w postaci zespołu ram wypełnionych drobną kratką. $\mathrm{Na}$ środkowej ramie umieszczono okrągły emblemat zawierający drzewo i napis „Ver sacrum”, który stał się potem logotypem jurandowskiego ośrodka. Warto nadmienić, że koszty budowy organów pokryte zostały z różnego rodzaju loterii, składek i darowizn (Walter, Orgelbau 103). W tym celu powołano Gesellschaft der Freunde der Orgel Ver sacrum e. V., na czele którego stanął późniejszy nadburmistrz Wrocławia Hans Fridrich (Lönnecker 13). Dużego

\footnotetext{
${ }^{1}$ Wymienione publikacje błędnie podają, że w manuale Oberwerk znajdował się głos Vox Humana 8 '.
} 
wsparcia udzielili członkowie: Finkensteiner Bund Singbewegung, Berneuchener Bewegung ${ }^{2}$ oraz Evangelischer Presseverband für Schlesien. Datki napływały nawet ze Skandynawii i Afryki. Swój wkład pieniężny przekazała także Spółdzielnia Energetyczna Kłodzko-Jurandów (Der Gebirgsbote).

Organy, oznaczone jako opus 1400 firmy Sauer, liczyły 25 głosów (w tym 20 głosów realnych i 5 transmisji w pedale z Hauptwerku) rozdzielonych na dwa manuały i pedał. Zespół brzmieniowy drugiej klawiatury zamknięty został w szafie ekspresyjnej (żaluzji). W instrumencie zastosowano pneumatyczną trakturę rejestrów i gry z wiatrownicami typu kieszonkowego (Taschenlade). Powietrze dostarczały dwa miechy magazynowe. Większy wyposażony był w pojedynczy podawacz o napędzie nożnym. Do miechów podłączona była dmuchawa elektryczna.

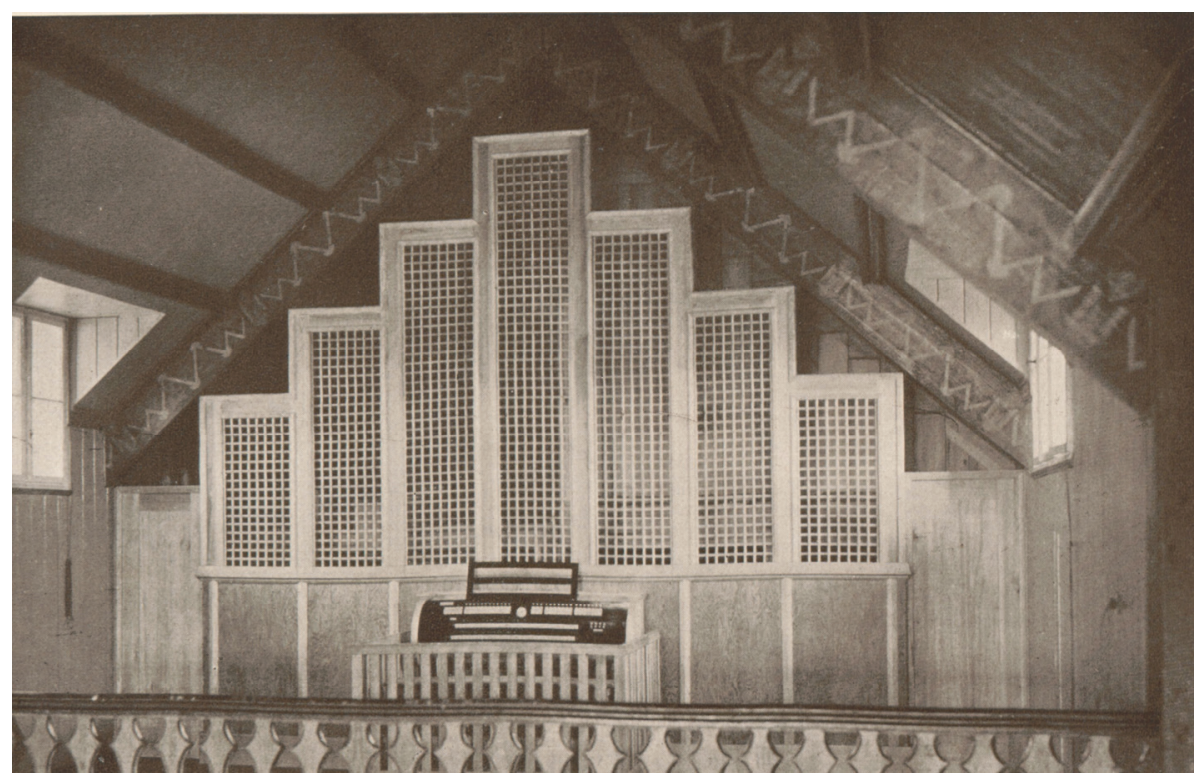

Fotografia 2. Organy Ver sacrum (Musik und Kirche, z. 1, 1930)

Instrument zaprezentowano podczas Tygodnia Muzycznego (Erste schlesische Freizeit Musik und Kirche) trwającego od 30 września do 7 października 1929 r. Uczestniczyło w nim ponad 140 osób, głównie nauczycieli, księży, organistów oraz chórmistrzów (Ramin 36; Walter, Orgelbau 103). Ze specjalnym koncertem wystąpili: Günther Ramin (1898-1956), organista kościoła

\footnotetext{
${ }^{2}$ Ewangelicki ruch odnowy religijnej powstały w latach dwudziestych XX wieku.
} 
św. Tomasza w Lipsku, oraz Walter Tappolet (1897-1991) z Zurychu. W programie recitalu znalazły się następujące utwory:

- Georg Friedrich Händel, Orgelkonzert F-dur (z orkiestrą smyczkową);

- Johann Sebastian Bach, Preludium und Fuge C-dur; Triosonate G-dur; Fantasie G-dur; partita Sei gegrüßet Jesu gütig oraz kilka preludiów chorałowych;

- Dietrich Buxtehude, fantazja Wie schön leuchtet der Morgenstern; Präludium und Fuge F-dur;

- Franz Tunder, fantazja Komm heiliger Geist;

- Georg Böhm, partita Ach wie flüchtig, ach wie nichtig;

- Johann Pachelbel, Toccata e-moll (wyk. W. Tappolet);

- Samuel Scheidt, psalm Jesus Christus unser Heiland;

- Jan Pieterszoon Sweelinck, wariacje na temat Mein junges Leben hat ein End (wyk. W. Tappolet);

- Girolamo Frescobaldi, Canzona festo tono;

- Michael Praetorius, hymn A solis ortus (wyk. W. Tappolet);

- Günther Raphael, partita Ach Gott vom Himmel, sieh darein;

- Günther Ramin, Orgelchoralsuite;

- Heinrich Kaminski, Choralsonate (wyk. W. Tappolet).

Główne uroczystości odbyły się w niedzielę 6 października (Glezzer-Herbstein). Wzięli w nich udział nie tylko zaproszeni goście i uczestnicy Tygodnia Muzycznego, ale także duża liczba mieszkańców Kłodzka i okolic. Akademię rozpoczął wspólny śpiew staroniemieckiej pieśni Heinricha Isaaca przy akompaniamencie organów. Podniosłą przemowę wygłosił twórca ośrodka a zarazem radca szkolny Poppe. Przybliżył program ideowy związany z budową organów oraz podziękował wszystkim, którzy przyczynili się do ich powstania. Podkreślił, że wspólny śpiew jest czynnikiem jednoczącym ludzi i sposobem kształtowania nowego narodu mającego w pamięci tych wszystkich, którzy ponieśli śmierć w obronie ojczyzny. Swoje wystąpienie zakończył słowami: „Dlatego też organy poświęcone będą tym wszystkim, którzy zmarli jako świeży zasiew dla naszego narodu!"3 (Glezzer-Herbstein).

Głos zabrał także Hans Klein (1892-1973), dyrektor szkoły z Karniowa i przedstawiciel Niemców sudeckich, którzy wsparli finansowo budowę organów. Instrument symbolizował także ich ofiarę oraz dążenia zjednoczeniowe. Oficjalną część uroczystości zakończył wspólny śpiew Deutsches Weihelied Walthera Hensela przy akompaniamencie organów.

3 „So sei die Orgel geweiht dem Andenken derer, die da starben als frische Saal für unser Volk!” (wszystkie thumaczenia pochodzą od autora). 
Po krótkiej przerwie rozpoczął się koncert inauguracyjny w wykonaniu Walthera Teppoleta. Program obejmował następujące utwory:

- Johann Pachelbel, Toccata e-moll;

- Heinrich Scheidemann, chorał Jesu, du wollest uns weisen;

- Jan Pieterszoon Sweelinck, wariacje na temat Mein junges Leben hat ein End;

- Johann Sebastian Bach, Fantasie G-dur.

Już po zakończonych uroczystościach, na łamach czasopisma Musik und Kirche, ukazał się bardzo pochlebny tekst o organach pióra Günthera Ramina, który podczas wspomnianego Tygodnia Muzycznego dokonał próby instrumentu (Ramin 34-37) ${ }^{4}$. W artykule nie zabrakło jednak drobnej krytyki. Ramin za zbyteczne uznał zainstalowanie wałka crescendo (uzasadniał to brakiem płynnego, progresywnego przejścia) oraz zwrócił uwagę na brak w dyspozycji I manuału słabiej zintonowanych głosów labialnych cztero- i dwustopowych (była tylko dość mocna oktawa). Zaznaczył, że sugestie w tym względzie zostały zgłoszone jeszcze na miejscu i firma Sauer miała dokonać modyfikacji w tym zakresie. Zauważył ponadto, że sekcja pedału z dwoma realnymi głosami nie ma wprawdzie własnego, specyficznego brzmienia, ale braki te niwelowały zastosowane transmisje. $Z$ uznaniem wyraził się o wykorzystanych $\mathrm{w}$ dyspozycji głosach językowych, tak przydatnych $\mathrm{w}$ interpretacji muzyki Scheidta, Buxtehudego czy Bacha. Za szczególnie udany uznał głos Singend Cornet 2 ' w pedale.

Zgodnie z powyższą zapowiedzią firma Sauer dokonała niewielkiej zmiany w dyspozycji Hauptwerku poprzez dodanie głosu Flachflöte 2' oraz zastosowanie jego transmisji w pedale. Ostatecznie więc instrument liczył 27 głosów, w tym 21 głosów realnych i 6 transmisji:

\footnotetext{
${ }^{4}$ „Die wohldurchgebildete Eigenart der einzelne Register-Individualitäten, die sich im Gesamt dann zur wundervollen Gemeinschaft qualitativ ausgerichteter Klänge fügen, ist allerdings der Crescendo-Walze gefährlich geworden, die einen lückenlos fortschreikenden Übergang nicht gestattet. Mir scheint auch die Walze für Orgeln von nur 20 Stimmen dieser Konstruktion (mit den typischen Eigentümlichkeiten der Barock-Orgelregister) durchaus entbehrlich. Bei der Disposition des ersten Manuals wird der Mangel eines schwächer gehaltenen Labial 4 oder 2 Fußes (es ist ja nur die ziemlich kräftige Oktave 4' da) recht fühlbar. Doch wurden diesbezügliche Anregungen schon von den maßgebenden Leuten in Hassitz lebhaft aufgerissen, und vielleicht wird bei Drucklegung dieser Zeilen die Vervollständigung des Werkes bereits erfolgt sein. Daß das Pedal mit nur zwei selbständigen Registern keinen besonderen Eigenklang besitzt, ist ja begreiflich, trotzdem läßt es sich durch die Transmissionen vom I. Manual her wenigstens in Bezug auf die Klarheit der Darstellung sehr gut verwerken. Die charakteristischen Zungenstimmen aus der Barockzeit (Dulcian 16', Krummhorn 8', Singend Cornet 2') sind bei der Gestaltung ganz besonders der rein kultischen Orgelmusik, also bei den Orgelchorälen Samuel Scheidts, Tunders, Böhms, Buxtehudes und Bachs von höchstem Werk; ganz hervorragend ist der Singend Cornet 2' gelungen”.
} 


$\begin{array}{lll}\text { Hauptwerk } & \text { Oberwerk } & \text { Pedal } \\ \mathrm{C}_{\mathrm{g}}{ }^{3} & \mathrm{C}-\mathrm{g}^{3} & \mathrm{C}^{1} \mathrm{f}^{1} \\ & \text { żaluzja } & \end{array}$

Prinzipal 8'

Rohrflöte $8^{\prime}$

Oktave 4'

Gemshorn 4'

Flachflöte 2'

Rauschpfeife 2 f. ${ }^{5}$

Zimbel 3 f. ${ }^{6}$

Dulcian 16'
Violflöte 8'

Quintatön 8'

Liebl.-Gedeckt 8'

Prinzipal 4'

Gedecktflöte 4'

Quinte 2 2/3'

Oktave 2'

Nachthorn 2'

Terz $13 / 5^{\prime}$

Blockflöte 1'

Krummhorn 8'
Subbaß 16

Rohrflöte $8^{\prime}$ (Tr.)

Prinzipal 8' (Tr.)

Oktave 4' (Tr.)

Flachflöte 2' (Tr.)

Rauschpfeife 2 f. (Tr.)

Dulcian 16' (Tr.)

Singend Cornett 2'

Połączenia: Oberwerk/Hauptwerk, Hauptwerk/Pedal, Oberwerk/Pedal

Kombinacje: fr. Comb., Tutti

Urządzenia dodatkowe: Handreg. „an”; Tremolo O.; Walzengruppen: Labiale Gruppe I, Labiale Gruppe II, Zungen Gruppe, Manual-koppeln, Pedal-koppeln; Einzelausschaltungen: Krummhorn 8' II, Dulcian 16' I, Dulcian 16' P, Sing. Corn. 2' P; wskaźnik zegarowy

Urządzenia nożne: Crescendo \& Decrescendo (wałek); Schwell Oberwerk (pedał); Oberwerk z. Hauptwerk; Hauptwerk z. Pedal; Oberwerk z. Pedal; Handreg. „an”; fr. Comb., Tutti

Od momentu inauguracji instrument był bardzo intensywnie wykorzystywany do celów edukacyjnych i koncertowych, czego przykładem mogą być Warsztaty Bachowskie, które odbyły się w Wielkim Tygodniu 1931 r. (Habelschwerdter). Uczestniczyło w nich ponad 60 osób (w tym wielu organistów) z różnych stron Niemiec, Austrii, Czechosłowacji, Polski oraz z Wolnego Miasta Gdańska.

Organy, pomimo zmiany przeznaczenia ośrodka, przetrwały do końca II wojny światowej. W 1945 r. zostały (za zgodą władz państwowych) w nie do końca wyjaśnionych okolicznościach przekazane do kościoła pw. św. Trójcy w Strzelcach k. Kutna (Brylla, Udokumentowane 55-56; Staniszewski; Woźniak). Informują o tym m.in. tabliczki umieszczone na obudowie instrumentu o następującej treści: „Z inicjatywy i dzięki zasługom ks. prob. Al. Cegłowskiego organy zakupione staraniem całej parafii przy wydatnej pomocy Eugeniusza Boreckiego. Poświęcał ks. dziekan kutnowski Bronisław Pągowski. Pierwszy

\footnotetext{
$52^{2} / 3^{\prime}+1^{\prime}$

${ }^{6}$ Głos dwu- i trzyrzędowy.
} 
zagrał Bernard Hinek 20 stycznia 1946 r."”. Niestety już na przełomie lat siedemdziesiątych i osiemdziesiątych XX wieku instrument był niesprawny i nieużywany. Udało się go uruchomić podczas remontu w 1993 r., lecz od tego czasu jego stan stale się pogarszał. Doraźne naprawy (z reguły niefachowo przeprowadzone) nie przywróciły pełnej funkcjonalności organom. W 2012 r. dokonano wymiany większego oryginalnego miecha magazynowego na miech pływakowy. Obecnie instrument jest w bardzo złym stanie techniczno-muzycznym, co uniemożliwia jego prawidłową eksploatację: działa jedynie kilka głosów, zdemontowana została znaczna liczba piszczałek, odłączona została (poprzez obcięcie ołowianych rurek traktury) sekcja Oberwerku. Organy wymagają podjęcia gruntownych prac remontowych.

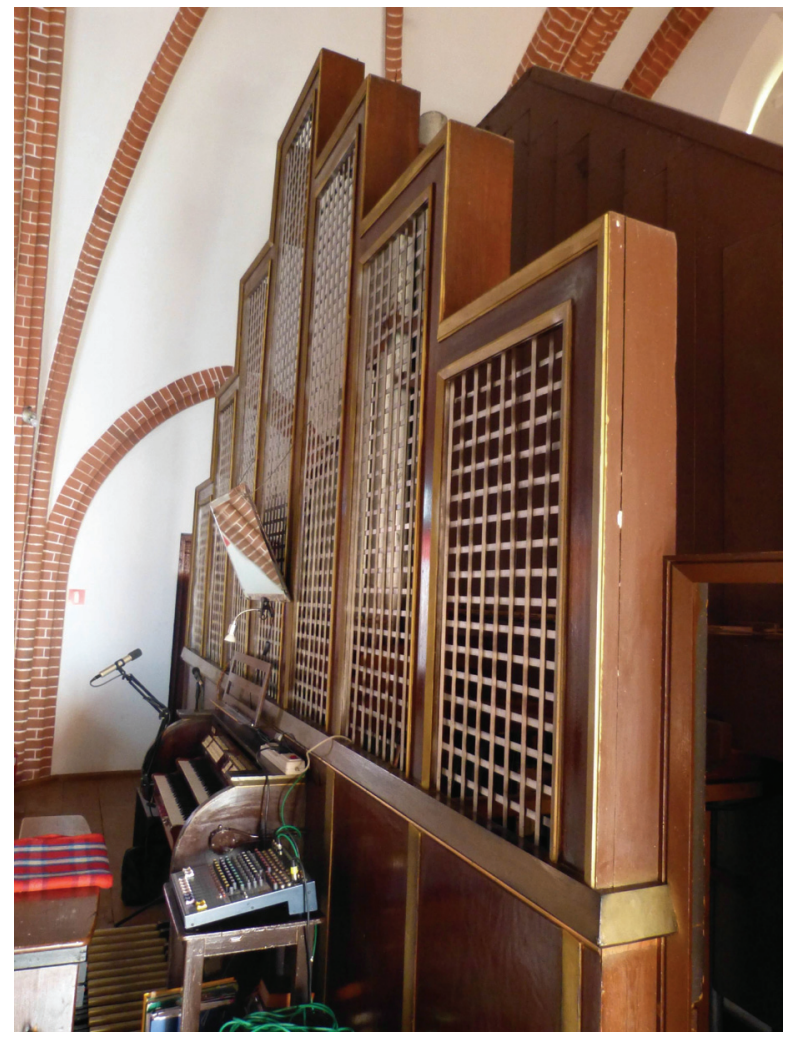

Fotografia 3. Organy w kościele parafialnym w Strzelcach

${ }^{7}$ Autor składa podziękowania ks. proboszczowi Tadeuszowi Świątkowi za okazaną życzliwość i udostępnienie instrumentu (oględziny 6 lutego 2021 r.) oraz p. organiście Zbigniewowi Dąbrowskiemu za udzieloną pomoc i informacje. 
Kończąc niniejszy szkic, warto podkreślić, że specyfika omawianego instrumentu polegała na przypisaniu mu przesłania ideowego. Znalazło to swój wyraz nie tylko w nazwie organów, ale i miejscu ich instalacji. Zastosowane $\mathrm{w}$ jurandowskich organach rozwiązania brzmieniowo-konstrukcyjne rozpatrywać należy w kontekście zarówno Orgelbewegung, jak i ruchu śpiewaczego. Zdaniem Willibalda Gurlitta oba stanowiły ogniwo ogólnoniemieckiego ruchu odnowy muzycznej, propagowanego przez młodzież powracającą z I wojny światowej (Walter, Orgelbau 103). O ile instrument w warstwie brzmieniowej (dyspozycyjnej) nawiązywał do ideału organów z czasów Bacha, o tyle jego mechanizm gry prezentował osiągnięcia XX wieku. Były to typowe cechy pierwszych lat niemieckiego Ruchu Odnowy Organów, kiedy to próbowano pogodzić najnowsze tendencje $\mathrm{z}$ prądami neobarokowymi. W organach Ver sacrum do głosu wyraźnie doszła postawa kompromisowa polegająca na połączeniu „starego" z „nowym”, co jeszcze przed ich powstaniem w następujący sposób podsumował Fritz Haufe: „Oczywistym jest, że przy budowie tych organów zostanie wykorzystany postęp techniczny. Nie kopiujemy wprost organów barokowych. Prawdopodobnie także, jak wyjaśnił Ramin w Jurandowie, nie spełnilibyśmy woli dawnych organmistrzów, ślepo naśladując ich organy. Wiemy, że w swoich organach układali różne dyspozycje, w zależności od miejsca i celu ówczesnej parafii. Ważne jest raczej, by nowe organy tworzyć w ogólnym duchu tej starej sztuki organmistrzowskiej. Christhard Mahrenholz z Groß-Lengden k. Getyngi sporządził wytyczne do budowy takich odnowionych organów barokowych, według których są budowane także jurandowskie organy" ${ }^{8}$ (Haufe 312 ).

\section{BIBLIOGRAFIA}

Brylla, Wolfgang J. „Udokumentowane translokacje dolnośląskich organów”. Organy na Śląsku IV, red. Julian Gembalski, Wydawnictwo Akademii Muzycznej im. Karola Szymanowskiego w Katowicach, 2012, ss. 47-75.

Brylla, Wolfgang J. „Utracone - odnalezione. Organy Ver sacrum”. Sudety, nr 3, 2011, ss. 20-21.

${ }^{8}$ „Selbstverständlich wird man technische Fortschritte sich beim Bau dieser Orgel zunutze machen. Wir kopieren nicht einfach Barockorgeln. Wir würden wahrscheinlich auch, wie Ramin in Hassitz ausführte, gar nicht dem Willen der alten Orgelbaumeister entsprechen, wenn wir ihre Orgeln sklavisch nachahmten. Wir wissen, daß sie nach dem Raum und dem Sinn der jeweiligen Gemeinde ihre Orgeln oft sehr verschieden disponiert haben. Es gilt vielmehr aus dem Gesamtgeist dieser alten Orgelbaukunst eine neue Orgel zu schaffen. Christhard Mahrenholz in Groß-Lengden bei Göttingen hat Richtlinien für den Bau solcher erneuerter Barockorgeln aufgestellt, nach ihnen ist auch die Hassitzer Orgel gebaut". 
Burgemeister, Ludwig. Der Orgelbau in Schlesien. Wyd. 2, Verlag Wolfgang Weidlich Frankfurt am Main, 1973.

Busch, Hermann J. „Orgelbewegung”. Lexikon der Orgel, red. Hermann J. Busch, Matthias Geuting, wyd. 3, Laaber-Verlag, 2011, ss. 533-536.

Członkowska-Naumiuk, Małgorzata. „Italska święta wojna”. Mówiq wieki, nr 5, 2014, ss. 21-25.

Der Gebirgsbote, nr 274, 1929.

Falkenberg, Hans-Joachim. Die Orgelwerkstatt Wilhelm Sauer 1910-1995. Musikwissenschaftliche Verlagsgesellschaft Kleinblittersdorf, 1998.

Glezzer-Herbstein. „Orgelweihe im Jugendhof Hassitz”. Der Gebirgsbote, nr 279, 1929.

Habelschwerdter Anzeiger, nr 27, 1931.

Haufe, Fritz. „Die Orgel Ver Sacrum im Jugendhof Hassitz”. Deutsche Sängerschaft, nr 8, 1929, ss. 308-314.

Kraus, Eva. Das Deutsche Jugendherbergswerk 1909-1933. Programm - Personen - Gleichschaltung. Pro Business Verlag Berlin, 2013.

Lönnecker, Harald. „«Nicht Erz und Stein, Musik soll unser Denkmal sein!» Die Singbewegung und das nie gebaute Denkmal der Deutschen Sängerschaft (Weim. CC)", www.burschenschaftsgeschichte.de/ pdf/loennecker_singbewegung.pdf. Dostęp 21.02.2021.

Menzel, Wilhelm, redaktor. Richard Poppe. Ein Leben für die Jugend, Heimat und Volk. Dortmund, 1966.

Preis, Paul. Musik- und Theaterleben von Stadt und Kreis Glatz, t. 1: Stadt Glatz. Lüdenscheid, 1967.

Preis, Paul. Musik- und Theaterleben von Stadt und Kreis Glatz, t. 2: Kreis Glatz. Lüdenscheid, 1969.

Ramin, Günther. „Die Orgel, Ver Sacrum im Jugendhof Hassitz”. Musik und Kirche, nr 1, 1930, ss. 34-37.

Stownik geografii turystycznej Sudetów, red. Marek Staffa, t. 15, Wydawnictwo I-BiS, 1994.

Staniszewski, Paweł. „Szczegóły parafii Świętej Trójcy w Strzelcach”, www.diecezja.lowicz.pl/ parafia/swietej-trojcy-w-strzelcach. Dostęp 9.02.2021.

Stępowski, Jarosław. „Zabytkowe organy Kłodzka. Wpływy czeskie”. Zeszyty Muzeum Ziemi Kłodzkiej, nr 10, 2009, ss. 125-151.

Walter, Rudolf. „Orgelbau in Schlesien zwischen den beiden Weltkriegen”. Der Orgelbau in Schlesien, red. Ludwig Burgemeister, wyd. 2, Verlag Wolfgang Weidlich Frankfurt am Main, 1973, ss. 95-115.

Walter, Rudolf. „Die Orgeln im Musiksaal der Universität Breslau”. Jahrbuch der Schlesischen Friedrich-Wilhelms-Universität zu Breslau, nr 21, 1980, ss. 261-279.

Woźniak, Piotr. „Kościół Trójcy Świętej”. Musicam Sacram, https://musicamsacram.pl/instrumenty/ opis/2375-Strzelce-Kosciol-Trojcy-Swietej. Dostęp 9.02.2021.

Zeitschrift für Instrumentenbau, nr 11, 1930, s. 398. 


\section{IKONA NIEMIECKIEGO ORGELBEWEGUNG - \\ ORGANY OŚRODKA JUGENDHOF HASSITZ \\ W KŁODZKU-JURANDOWIE (GOSZYCACH)}

Streszczenie

Do pierwszych instrumentów powstałych na Śląsku w duchu Orgelbewegung należały organy Młodzieżowego Ośrodka Wypoczynkowo-Szkoleniowego w Kłodzku-Jurandowie. Ośrodek ten, założony z inicjatywy Richarda Poppego, stał się centrum odnowy ruchu śpiewaczego dla Niemiec wschodnich. Instrument nazwany Ver sacrum, czyli „Święta wiosna” miał upamiętniać i przypominać tych wszystkich, którzy poświęcili i oddali swoje życie za ojczyznę (zwłaszcza poległych w czasie I wojny światowej). Organy zostały wybudowane w 1929 r. przez firmę Sauer z Frankfurtu n. Odrą (opus 1400). Posiadały 27 głosów (w tym 21 realnych) i trakturę pneumatyczną z wiatrownicami typu kieszonkowego. Dyspozycję głosową opracował czołowy przedstawiciel ruchu Orgelbewegung dr Christhard Mahrenholz. O ile w warstwie brzmieniowej instrument nawiązywał do ideału organów z czasów Bacha, to jego mechanizm gry prezentował osiągnięcia XX wieku. Pod koniec 1945 r. organy zostały przekazane do kościoła parafialnego Trójcy Świętej w Strzelcach koło Kutna.

Słowa kluczowe: organy; Ver sacrum; Orgelbewegung; Kłodzko-Jurandów; Strzelce k. Kutna.

\section{THE ICON OF THE GERMAN ORGELBEWEGUNG: THE JUGENDHOF HASSITZ ORGAN IN KŁODZKO-JURANDÓW (GOSZYCE)}

\section{Su m m a ry}

One of the first instruments that was produced in Silesia in the spirit of the Orgelbewegung was the organ of the Youth Leisure and Training Centre in Kłodzko-Jurandów. This centre, founded on the initiative of Richard Poppe, became a source of renewal for the Singbewegung in Eastern Germany. The instrument, called Ver sacrum (Sacred Spring), was meant to commemorate and remind everyone of all those who had sacrificed themselves and given their lives for their Fatherland (in particular, the fallen soldiers of the First World War). The organ was built in 1929 by the Sauer company from Frankfurt/Oder (opus 1400). It had 27 stops (including 21 real stops), and pneumatic key and stop action with Taschenlade windchests. The organ disposition was designed by Christhard Mahrenholz, Ph.D., one of the leaders of the Orgelbewegung. Even though, musically, the instrument draws on the organ ideal from the Bach era, its mechanism perfectly reflects the achievements of organ construction of the twentieth century. In late 1945, the instrument was relocated to the Trinity parish church in Strzelce near Kutno.

Keywords: organ; Ver sacrum; Orgelbewegung; Kłodzko-Jurandów; Strzelce near Kutno. 